\title{
Variation of ursolic acid content in flowers of ten Iranian pomegranate (Punica granatum L.) cultivars
}

\author{
Fatemeh Sharifyan ${ }^{1}$, Seyed Abbas Mirjalilii ${ }^{*} \mathbb{0}$, Mohammad Fazilati ${ }^{1}$, Elahe Poorazizi ${ }^{3}$ and Saeed Habibollahi ${ }^{4}$
}

\begin{abstract}
Background: Ursolic acid (UA) is an important bioactive component in many traditional medicinal plants including pomegranate (Punica granatum L.) flower.

Methods: This study presents the HPLC analysis of UA contents of ten cultivars of pomegranate flower grown in Iran. The UA contents of fallen flowers of pomegranate were given in each cultivar.

Results: Remarkable quantities of UA were found in ten cultivars of Iranian pomegranate flower evaluated (21.736 to $15.119 \mathrm{mg} / \mathrm{g}$ ). Lower quantities of UA were determined in pomegranate fallen flowers (16.763 to $5.754 \mathrm{mg} / \mathrm{g}$ ).

Conclusion: UA values obtained from Iranian cultivars of pomegranate flowers are very significant when compared with other sources of UA. All of the analyzes suggested that the Iranian pomegranate flowers (including flowers on branches and fallen flowers) might be an excellent UA rich source.
\end{abstract}

Keywords: Ursolic acid, Pomegranate flower, HPLC

\section{Introduction}

Ursolic acid (UA, 3ß-hydroxy-12-urs-12-ene-28-oic acid) (Fig. 1) as an ursane-type pentacyclic triterpene, is a constituent of some medicinal plants [1]. UA possesses considerable pharmacological effects including hepatoprotective [2, 3], immunomodulatory [4], antiinflammatory $[5,6]$, antidiabetic $[7,8]$, antitumor $[9,10]$, antiulcer [11] and anticancer activities [12, 13]. Recently UA has attracted increasing attention due to its multifunctional anticancer activities $[13,14]$. Anti-inflammatory and anti-proliferative, anti-metastatic, proapoptotic, and anti-angiogenic abilities of UA have been reported in both in vivo and in vitro models of cancer $[13,15]$.

Punica granatum Linn. (Punicaceae), commonly known as pomegranate, is a small tree, extensively cultivated in the Middle East, North Africa, the Mediterranean and in parts of Asia [16]. The plant has an immense

*Correspondence: abmirjalili@gmail.com

${ }^{2}$ Imam Khomeini Higher Education Center, Agricultural Research, Education and Extension Organization (AREEO), Tehran, Iran

Full list of author information is available at the end of the article therapeutic value. Pomegranate, especially its flowers, has been widely used in Ayurvedic, Chinese and Unani medicine systems [17]. Since the flowers are strongly astringent and antidiabetic, a decoction of pomegranate flowers stops bleeding and remedies tympanitis. The flowers are also used in traditional Chinese medicine to cure graying of hair in young men, to treat injuries from falls and to treat chronic diarrhea, especially in children $[18,19]$. Pomegranate flowers contain multiple secondary metabolites, the most abundant of which are polyphenols such as gallic acid, ellagic acid and ethyl brevifolincarboxylate; followed by triterpenes including ursolic, oleanolic, maslinic and asiatic acids. These compounds have shown strong biological activities and medicinal values [20,21]. As a natural medicine, the type and amount of bioactive ingredients in pomegranate flowers can vary considerably according to the environmental cultivations, soil, water supply, light, geographical origin, the cultivar type used and the time when it is harvested [22]. This study evaluates the variation of UA content in ten cultivars of pomegranate flower grown in Iran, as determined by HPLC analysis. Also in each cultivar, we compared the 


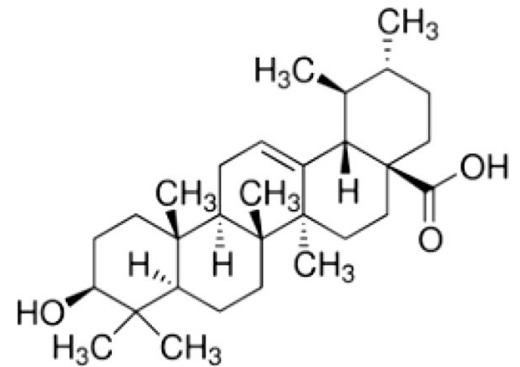

Fig. 1 Structure of ursolic acid (UA, 3 $\beta$-hydroxy-12-urs-12-ene-28-oic acid)

UA content of flowers picked from branches with fallen flowers.

\section{Materials and methods Chemicals}

Ursolic acid standard (European Pharmacopoeia Reference Standard) was purchased from Sigma-Aldrich to control biological and pharmaceutical products. Methanol and water of HPLC grade were obtained from Merck (Germany). Analytical grade Ethanol was purchased from Merck (Germany).

\section{Plant materials}

Flowers of ten Iranian pomegranate cultivars ('Golnar', 'Ghorj Tafti Torsh,' 'Jangal Sefidrood, 'Shirin Bihasteh Mehriz,' 'Zagh Sefid Yazd,' 'Alack Zood Ras', 'Shirin Siyah Saveh, 'Malas Daneh Zard Yazd,' 'Shirin Shahbar', 'Ghojagh Shahpar Varamin') were collected from Pomegranate trees, which identified originally by a group of botanists, cultivated in the Pomegranate Genotypes Resources Collection (PGRC) subordinate to AREEO (Agricultural Research, Education and Extension Organization, Ministry of Agriculture) in Isfahan Province, Iran in May 2016. In order to compare the UA contents, intact fallen flowers in each cultivar were collected at the same time. The perfect flowers were dried at $105^{\circ} \mathrm{C}$ for $15 \mathrm{~min}$, and then at $65^{\circ} \mathrm{C}$ for 2 days in a hot-air oven.

\section{Quantification of UA by HPLC \\ Calibration curve}

Stock standard solution of UA was prepared by solving an adequate amount of UA in methanol to obtain an ultimate concentration of $1 \mathrm{mg} / \mathrm{mL}$. A serial dilution was made with methanol to prepare standard solutions at concentrations of $100,200,300$ and $400 \mu \mathrm{g} / \mathrm{mL}$, from each of which $20 \mu \mathrm{L}$ was utilized to plot a standard curve for UA.

\section{High-performance liquid chromatography system}

Quantification of UA was performed on a SY-8100 system, equipped with SY-8100 HPLC pump, a 7725i manual sample injector, a variable-wavelength UV detector, and SY-8000 HPLC software. The analytical column that was used was Venusil MP C18 $(250 \mathrm{~mm} \times 4.6 \mathrm{~mm}, 5 \mu \mathrm{m})$. The isocratic mobile phase was made of methanol and $0.1 \mathrm{M}$ Phosphate buffer $(\mathrm{PH}=3,90: 10)$. The flow rate was $0.9 \mathrm{~mL} / \mathrm{min}$ and the elute was monitored at $210 \mathrm{~nm}$. The column temperature was kept constant at $21 \pm 1{ }^{\circ} \mathrm{C}$. Under these optimized experimental conditions, the HPLC method was applied to analyze the contents of UA in ten cultivars of Iranian pomegranate flower.

\section{Preparation of crude extract}

In each cultivar, the powder of pomegranate flowers $(1 \mathrm{~g})$ was ultrasonically extracted with $20 \mathrm{~mL} 90 \%$ ethanol for $50 \mathrm{~min}$ at $40{ }^{\circ} \mathrm{C}$, and then it was filtered. For HPLC analysis, the extracts were passed through a $0.45 \mu \mathrm{m}$ membrane filter. The peaks related to UA were identified by the retention time and the co-injection test with the standard compound. The UA concentration for all samples was calculated using the peak area based on the standard curve.

\section{Precision and recovery studies}

To evaluate the intra-day precision of the HPLC method, 200, 300 and $400 \mu \mathrm{g} / \mathrm{mL}$ standard solutions of UA were injected several times $(n=5)$ over a day. These studies were repeated on different days $(n=5)$ to evaluate the inter-day precision.

In addition, to test the recovery of the developed method, dried plant powder $(1 \mathrm{~g})$ was added with $2 \mathrm{mg}$ UA standard before extraction. Follow-up extraction along with HPLC analysis was performed as described above in detail. The recovery evaluation was as follows:

$$
\text { Recovery }(\%)=(\mathrm{A}-\mathrm{B}) / \mathrm{C} \times 100
$$

In which, $\mathrm{A}$ is the result after adding standard, $\mathrm{B}$ denotes the amount of sample before adding standard, and $\mathrm{C}$ stands for the amount of standard added.

\section{Statistical analysis}

All data are the mean of three replicates and are presented as mean \pm standard deviation (SD). Statistical analysis was performed with the Statistical Analysis System (SAS Institute Inc., Cary, NC) [23].

\section{Results and discussion} HPLC separation optimization

Because there are no chromophore moieties in Triterpenoids' chemical structures, they indicate poor UV 
absorption, which is the main limitation in analyzing this group of compounds by employing UV detection. In this study, the detection wavelength was chosen at $210 \mathrm{~nm}$ for UA because it has better absorption and sensitivity at this wavelength. Based on methanol, acetonitrile, phosphate buffer and phosphoric acid, several mobile phases were tested in order to determine better separation and peak shapes. Finally, the mobile phase consisting of methanol (A) and phosphate buffer $(\mathrm{PH}=3)(\mathrm{B})$ with a ratio of 90:10 (A:B, v/v) was chosen. It was found that simply using methanol separation was unsatisfactory, but as an organic modifier with phosphate buffer solution $(\mathrm{pH}=3)$, methanol performed well. In this regard, adding phosphate buffer improved the separation and peak shapes by controlling $\mathrm{pH}$ without ion pairing for acidic compounds. A flow rate of $0.9 \mathrm{~mL} / \mathrm{min}$ was found appropriate to shorten the run time with no compromise for the peak resolution. The controlled column temperature of $21 \pm 1{ }^{\circ} \mathrm{C}$ was needed to get reproducible results. The optimized chromatographic conditions were subsequently applied for the analysis of UA content in ten different cultivars of pomegranate flower.

\section{UA distribution within pomegranate flowers}

Based on the above detection method, the UA contents in ten cultivars of Iranian pomegranate flowers (including flowers on branches and fallen flowers) were analyzed. The chromatographic retention time for UA was about $9.20 \mathrm{~min}$. The typical chromatograms of the UA standard and extracts of pomegranate flower and pomegranate fallen flower were shown in Fig. $2 \mathrm{a}-\mathrm{c}$, which indicate that UA in the pomegranate flower was successfully separated and identified, and that this HPLC system could be used to quantify the content of UA.

The mean values and standard deviations of UA contents in extracts of pomegranate flowers of ten Iranian cultivars are presented in Table 1.

The content of UA varied significantly $(\mathrm{P}<0.01)$ in the cultivars of Iranian pomegranate flowers analyzed in this study. UA contents ranged from 21.736 to $15.119 \mathrm{mg}$ of ursolic acid/g pomegranate flower dry powder, being highest in 'Shirin Bihasteh Mehriz' and lowest in 'Ghojagh Shahpar Varamin' cultivar. The average UA content of ten pomegranate flower cultivars was $19.226(\mathrm{mg} / \mathrm{g})$ significantly depending on the cultivar.
High UA levels were found in 'Shirin Bihasteh Mehriz' (21.736 mg/g), 'Malas Daneh Zard Yazd' (21.622 mg/g), 'Shirin Siyah Saveh' (20.517 mg/g), 'Alack Zood Ras' (20.294 mg/g), 'Golnar' (19.514 mg/g), 'Zagh Sefid Yazd' (19.089 mg/g), 'Shirin Shahbar' (19.06 mg/g) and 'Ghorj Tafti Torsh' (19.044 mg/g), but in 'Jangal Sefidrood' ( $16.268 \mathrm{mg} / \mathrm{g}$ ) and 'Ghojagh Shahpar Varamin' $(15.119 \mathrm{mg} / \mathrm{g})$, lower levels of UA were observed. Variations in the range of UA values observed in this study could be due to differences in cultivars used. Such variations can also suggest a variety of ecological functions throughout evolution. These possible functions include interactions between plants and herbivorous insects. UA is variously reported to possess anti-insect activity [24-26]. González-Coloma et al. [27] evaluated the general activity of pentacyclic triterpenes such as ursane and lupane, and explained their antifeedant effects on several pest insects (Leptinotarsa decemlineata, Myzus persicae and Spodoptera littoralis). In another study, of the five compounds isolated from the leaf extracts of Vitex negundo L., ursolic acid showed more effective antifeedant activity against the third instar larvae of castor semilooper [24]. Therefore, along with other biological activities of pentacyclic triterpenes, UA is probably related to its role in plant defenses against insects; hence, probably, cultivars of pomegranate flower with a higher UA content have been more exposed to herbivorous insects than those with less UA.

In order to compare the collected results with the UA values in pomegranate fallen flowers, the UA contents of fallen flowers in each cultivar are presented in Table 2.

UA was detected in the fallen flowers of all pomegranate cultivars analyzed in this study. Statistically, there were significant differences $(\mathrm{P}<0.01)$ between the UA contents of fallen flowers in different cultivars. For the fallen flowers, UA contents ranged from 16.763 to $5.754 \mathrm{mg}$ of Ursolic acid/g pomegranate flower dry powder, for cultivars of Shirin Siyah Saveh and Zagh Sefid Yazd, respectively. The average UA content of ten cultivars of pomegranate fallen flowers was $11.624(\mathrm{mg} / \mathrm{g})$. In each cultivar, the determined values of UA in pomegranate fallen flowers were remarkably lower than those in flowers picked from branches, on the average 1.65 times. These decreased levels of UA observed in fallen flowers probably happened after flowers fell from the trees and were related to environmental effects.

(See figure on next page.)

Fig. 2 HPLC chromatograms of pomegranate flowers extracts. a UA standard; b pomegranate flower extract (cv. Shirin Bihasteh Mehriz) ( $\times 5)$; c pomegranate fallen flower extract (cv. Shirin Bihasteh Mehriz) ( $\times 3)$. HPLC conditions-column: Venusil MP C18 (250 mm × $4.6 \mathrm{~mm}, 5 \mu \mathrm{m})$; mobile phase: methanol and $0.1 \mathrm{M}$ Phosphate buffer $(\mathrm{PH}=3,90: 10)$; flow rate: $0.9 \mathrm{~mL} / \mathrm{min}$; detection wavelength: $210 \mathrm{~nm}$; temperature: $21 \pm 1^{\circ} \mathrm{C}$; injection volume: $20 \mu \mathrm{L}$ 

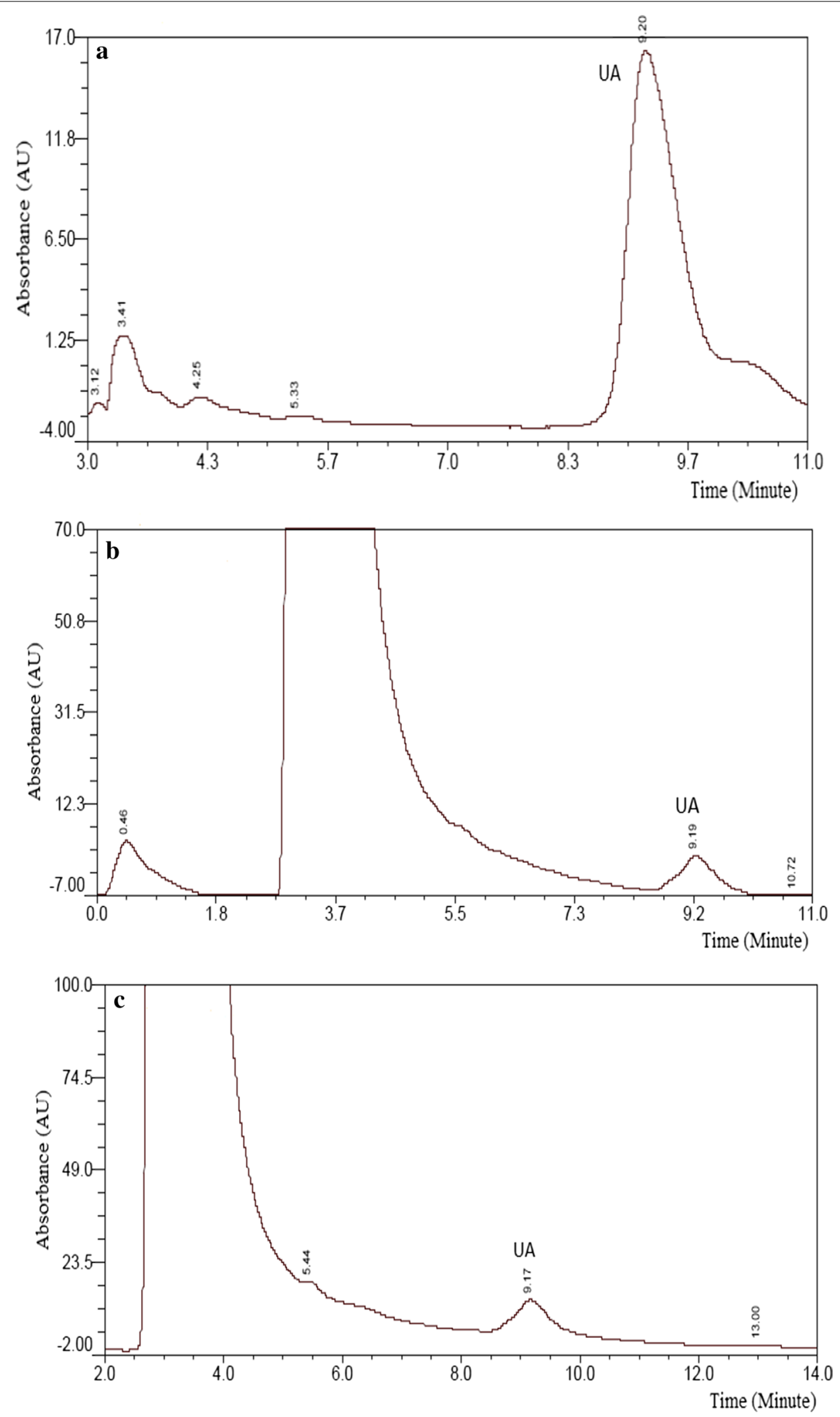
Table 1 The UA content in ten cultivars of Iranian pomegranate flower

\begin{tabular}{llc}
\hline Cultivar & Crude extract weight (g) ${ }^{\mathbf{a}}$ & $\begin{array}{l}\text { UA contents (mg/g } \\
\text { of pomegranate flower dry } \\
\text { powder) }\end{array}$ \\
\hline Golnar & & $19.514 \pm 0.890$ \\
Ghorj Tafti Torsh & $15.819 \pm 0.534$ & $19.044 \pm 0.231$ \\
Jangal Sefidrood & $14.821 \pm 0.737$ & $16.268 \pm 0.500$ \\
Shirin Bihasteh Mehriz & $15.096 \pm 0.253$ & $21.736 \pm 0.564$ \\
Zagh Sefid Yazd & $15.769 \pm 0.486$ & $19.089 \pm 0.962$ \\
Alack Zood Ras & $15.120 \pm 0.698$ & $20.294 \pm 0.306$ \\
Shirin Siyah Saveh & $15.237 \pm 0.298$ & $20.517 \pm 0.855$ \\
Malas Daneh Zard Yazd & $14.968 \pm 0.894$ & $21.622 \pm 1.00$ \\
Shirin Shahbar & $15.538 \pm 0.773$ & $19.063 \pm 0.486$ \\
Ghojagh Shahpar Varamin & $15.458 \pm 0.163$ & $15.119 \pm 0.663$ \\
\hline
\end{tabular}

Data are means $(n=3) \pm$ standard deviation

a The weight of the extract is related to the liquid extract

Table 2 The UA content in ten cultivars of Iranian pomegranate fallen flowers

\begin{tabular}{lcc}
\hline Cultivar & Crude extract weight (g) $)^{\mathbf{a}}$ & $\begin{array}{l}\text { UA contents (mg/g } \\
\text { of pomegranate flower dry } \\
\text { powder) }\end{array}$ \\
\hline Golnar & & $9.269 \pm 0.378$ \\
Ghorj Tafti Torsh & $14.895 \pm 0.436$ & $12.153 \pm 0.399$ \\
Jangal Sefidrood & $14.655 \pm 0.837$ & $12.755 \pm 0.009$ \\
Shirin Bihasteh Mehriz & $15.104 \pm 0.859$ & $15.332 \pm 0.548$ \\
Zagh Sefid Yazd & $15.669 \pm 0.383$ & $5.754 \pm 0.435$ \\
Alack Zood Ras & $14.242 \pm 0.533$ & $11.755 \pm 0.826$ \\
Shirin Siyah Saveh & $15.311 \pm 0.728$ & $16.763 \pm 0.865$ \\
Malas Daneh Zard Yazd & $14.983 \pm 0.786$ & $10.042 \pm 0.332$ \\
Shirin Shahbar & $15.348 \pm 0.637$ & $15.763 \pm 0.304$ \\
Ghojagh Shahpar Varamin & $15.934 \pm 0.845$ & $6.658 \pm 0.586$
\end{tabular}

Data are means $(n=3) \pm$ standard deviation

a The weight of the extract is related to the liquid extract

Researchers have determined UA content in several different plants, including Ligustrum lucidum Ait. $(9.8 \mathrm{mg} / \mathrm{g})$ [28], Eriobotrya japonica Lindl. $(5.6 \mathrm{mg} / \mathrm{g})$ [29], Rosmarinus officinalis leaves $(15.8 \mathrm{mg} / \mathrm{g})$ [30] and Ziziphora clinopodioides Lam. (1.176 mg/g) [31]. Jager et al. [32] quantified the triterpene content of 39 plant material. They determined maximum concentration of UA in Rosmarinus officinalis leaves $(29.5 \mathrm{mg} / \mathrm{g})$, Salvia officinalis leaves $(18 \mathrm{mg} / \mathrm{g})$, Coffea arabica leaves $(18 \mathrm{mg} / \mathrm{g})$, Lavandula angustifolia leaves $(15.9 \mathrm{mg} / \mathrm{g})$ and Malus domestica peels (14.3 mg/g). Although UA is present in a wide variety of plants, our results showed that Iranian pomegranate flowers (including flowers on branches and fallen flowers) are good sources of UA.
Linearity, precision and recovery of the HPLC method

The linearity of the responses from the detector was studied for standard substance by plotting peak areas against the injected values. There was good agreement between the peak area and the standard values in the range of $100-400 \mu \mathrm{g} / \mathrm{mL}$ for UA. The regression equation and coefficient of determination were $[y=0.0006 x+18.142]$ $\left(\mathrm{R}^{2}=0.9955\right)$ for UA.

The inter-day and intra-day variations for the determination of UA were less than $3 \%$ at concentrations of 200 , 300 and $400 \mu \mathrm{g} / \mathrm{mL}$ (Table 3). The low values of \%RSD show the high accuracy of the method.

By mixing a suitable amount of quantified samples with the standard compound, recovery experiment was 
Table 3 Inter-day and intra-day precision for UA

\begin{tabular}{|c|c|c|}
\hline \multirow[t]{2}{*}{ Concentration $(\mu \mathrm{g} / \mathrm{mL})$} & \multicolumn{2}{|l|}{$\mathrm{RSD} \%$} \\
\hline & $\begin{array}{l}\text { Inter-day } \\
(n=5)\end{array}$ & $\begin{array}{l}\text { Intra-day } \\
(n=5)\end{array}$ \\
\hline 200 & 2.21 & 1.56 \\
\hline 300 & 1.99 & 1.63 \\
\hline 400 & 1.51 & 2.13 \\
\hline
\end{tabular}

conducted in order to confirm that the method was accurate, and the average recovery of UA was $100 \%$.

\section{Conclusion}

In this study, the investigation of UA contents of pomegranate flowers from ten cultivars grown in Iran was performed. Among the ten pomegranate flower cultivars researched, eight cultivars including 'Shirin Bihasteh Mehriz', 'Malas Daneh Zard Yazd,' 'Shirin Siyah Saveh, 'Alack Zood Ras', 'Golnar', 'Zagh Sefid Yazd,' 'Shirin Shahbar' and 'Ghorj Tafti Torsh are characterized by the highest content of UA and can be used as a rich source of UA for the synthesis of a wide variety of bioactive compounds such as food supplements and health products. However the results of this study showed that the UA content of pomegranate flowers is significantly reduced after falling from trees, but due to the high content of UA in pomegranate flowers and considering the fact that a large number of flowers of pomegranate trees fall and are discarded by farmers, the results suggested that the pomegranate fallen flowers are valued as a source of UA.

\section{Abbreviations}

CV.: cultivar; HPLC: high performance liquid chromatography; UA: ursolic acid.

\section{Acknowledgements}

The authors would like to thank Payame Noor University of Iran for financially supporting this research. We greatly thank Agricultural Research and Education Center of Isfahan, for providing and authenticating the plant materials used in this study.

\section{Authors' contributions}

Authors FSh and SAM designed the research and prepared the plant materials. FSH, SAM, MF, SH and EP performed the research and analyzed the data. All authors read and approved the final manuscript.

\section{Funding}

No funding was received for this study.

\section{Availability of data and materials}

The datasets used and analysed during the current study are available from the corresponding author on reasonable request.

\section{Competing interests}

The authors declare that they have no competing interests.

\section{Author details}

1 Department of Biology, Payame Noor University (PNU), Tehran, Iran.

${ }^{2}$ Imam Khomeini Higher Education Center, Agricultural Research, Education and Extension Organization (AREEO), Tehran, Iran. ${ }^{3}$ Department of Biochemistry, Najafabad Branch, Islamic Azad University, Najafabad, Iran. ${ }^{4}$ Department of Chemistry, Payame Noor University (PNU), Tehran, Iran.

Received: 24 September 2017 Accepted: 25 June 2019

Published online: 03 July 2019

References

1. Chen H, Gao Y, Wang A, Zhou X, Zheng Y, Zhou J (2015) Evolution in medicinal chemistry of ursolic acid derivatives as anticancer agents. Eur J Med Chem 6(92):648-655

2. Jin YR, Jin JL, Li CH, Piao XX, Jin NG (2012) Ursolic acid enhances mouse liver regeneration after partial hepatectomy. Pharm Biol. 50(4):523-528

3. Saravanan R, Viswanathan P, Pugalendi KV (2006) Protective effect of ursolic acid on ethanol-mediated experimental liver damage in rats. Life Sci 78(7):713-718

4. Saaby L, Jäger AK, Moesby L, Hansen EW, Christensen SB (2011) Isolation of immunomodulatory triterpene acids from a standardized rose hip powder (Rosa canina L.). Phytother Res 25(2):195-201

5. Ali MS, Ibrahim SA, Jalil S, Choudhary MI (2007) Ursolic acid: a potent inhibitor of superoxides produced in the cellular system. Phytother Res. 21(6):558-561

6. Zhang P, Cheng Y, Duan RD (2013) Ursolic acid inhibits acid sphingomyelinase in intestinal cells. Phytother Res. 27(2):173-178

7. Pérez Gutiérrez RM, Vargas Solis R, Garcia Baez E, Navarro YG (2009) Hypoglycemic activity of constituents from Astianthus viminalis in normal and streptozotocin-induced diabetic mice. J Nat Med. 63(4):393-401

8. Wang H, Wang Z, Guo W (2008) Comparative determination of ursolic acid and oleanolic acid of Macrocarpium officinalis (Sieb. et Zucc.) Nakai by RP-HPLC. Ind Crop Prod. 28(3):328-332

9. Suhagia BN, Rathod IS, Ezhava SB, Patel J (2013) A simple method for the isolation and estimation of ursolic acid in Alstonia Scholaris R. BR. Int J Pharm Sci Res. 4(7):2807

10. Wu HY, Chang $\mathrm{Cl}$, Lin BW, Yu FL, Lin PY, Hsu JL, Yen CH, Liao MH, Shih WL (2011) Suppression of hepatitis B virus x protein-mediated tumorigenic effects by ursolic Acid. J Agric Food Chem. 59(5):1713-1722

11. Ishikawa T, dos Santos Donatini R, Diaz IE, Yoshida M, Bacchi EM, Kato ET (2008) Evaluation of gastroprotective activity of Plinia edulis (Vell.) Sobral (Myrtaceae) leaves in rats. J Ethnopharmacol. 118(3):527-529

12. Kondo M, MacKinnon SL, Craft CC, Matchett MD, Hurta RA, Neto CC (2011) Ursolic acid and its esters: occurrence in cranberries and other Vaccinium fruit and effects on matrix metalloproteinase activity in DU145 prostate tumor cells. J Sci Food Agric 91(5):789-796

13. Shanmugam MK, Dai X, Kumar AP, Tan BK, Sethi G, Bishayee A (2013) Ursolic acid in cancer prevention and treatment: molecular targets, pharmacokinetics and clinical studies. Biochem Pharmacol. 85(11):1579-1587

14. Yang YC, Wei MC, Hong SJ, Huang TC, Lee SZ (2013) Development/ optimization of a green procedure with ultrasound-assisted improved supercritical carbon dioxide to produce extracts enriched in oleanolic acid and ursolic acid from Scutellaria barbata D. Don. Ind Crop Prod. 31(49):542-553

15. Shao JW, Dai YC, Xue JP, Wang JC, Lin FP, Guo YH (2011) In vitro and in vivo anticancer activity evaluation of ursolic acid derivatives. Eur J Med Chem. 46(7):2652-2661

16. Tehranifar A, Zarei M, Nemati Z, Esfandiyari B, Vazifeshenas MR (2010) Investigation of physico-chemical properties and antioxidant activity of twenty Iranian pomegranate (Punica granatum L.) cultivars. Sci Hortic. 126(2):180-185

17. Mirjalili SA (2015) A review on biochemical constituents and medicinal properties of pomegranate (Punica granatum L.). J Med Plants 4(56):1-22

18. Amjad L, Shafighi M (2013) Evaluation of antioxidant activity, phenolic and flavonoid content in Punica granatum var. Isfahan Malas flowers. Int J Agric Crop Sci. 5(10):1133

19. Kaur G, Jabbar Z, Athar M, Alam MS (2006) Punica granatum (pomegranate) flower extract possesses potent antioxidant activity and abrogates Fe-NTA induced hepatotoxicity in mice. Food Chem Toxicol. 44(7):984-993 
20. Yehya AH, Asif M, Tan YJ, Sasidharan S, Majid AM, Oon CE (2017) Broad spectrum targeting of tumor vasculature by medicinal plants: an updated review. J Herb Med. 9:1-13

21. Zhang L, Fu Q, Zhang Y (2011) Composition of anthocyanins in pomegranate flowers and their antioxidant activity. Food Chem. 127(4):1444-1449

22. Figueiredo AC, Barroso JG, Pedro LG, Scheffer JJ (2008) Factors affecting secondary metabolite production in plants: volatile components and essential oils. Flavour Frag J. 23(4):213-226

23. SAS Institute (1985) Statistical analysis system. SAS Inc., Cary

24. Chandramu C, Manohar RD, Krupadanam DG, Dashavantha RV (2003) Isolation, characterization and biological activity of betulinic acid and ursolic acid from Vitex negundo L. Phytother Res. 17(2):129-134

25. da Silva GN, Trindade FT, dos Santos F, Gosmann G, Gnoatto SC (2016) Larvicidal activity of natural and modified triterpenoids against Aedes aegypti (Diptera: Culicidae). Pest Manag Sci. 72(10):1883-1887

26. Mallavadhani UV, Mahapatra A, Raja SS, Manjula C (2003) Antifeedant activity of some pentacyclic triterpene acids and their fatty acid ester analogues. J Agric Food Chem. 51 (7):1952-1955

27. González-Coloma A, López-Balboa C, Santana O, Reina M, Fraga BM (2011) Triterpene-based plant defenses. Phytochem Rev. 10(2):245-260
28. Xia EQ, Yu YY, Xu XR, Deng GF, Guo YJ, Li HB (2012) Ultrasound-assisted extraction of oleanolic acid and ursolic acid from Ligustrum lucidum Ait. Ultrason Sonochem. 19(4):772-776

29. Xu XH, Su Q, Zang ZH (2012) Simultaneous determination of oleanolic acid and ursolic acid by RP-HPLC in the leaves of Eriobotrya japonica Lindl. J Pharm Anal. 2(3):238-240

30. Bernatoniene J, Cizauskaite U, Ivanauskas L, Jakstas V, Kalveniene Z, Kopustinskiene DM (2016) Novel approaches to optimize extraction processes of ursolic, oleanolic and rosmarinic acids from Rosmarinus officinalis leaves. Ind Crop Prod. 30(84):72-79

31. Tian S, Shi Y, Yu Q, Upur H (2010) Determination of oleanolic acid and ursolic acid contents in Ziziphora clinopodioides Lam. by HPLC method. Pharmacogn Mag. 6(22):116

32. Jäger S, Trojan H, Kopp T, Laszczyk MN, Scheffler A (2009) Pentacyclic triterpene distribution in various plants - rich sources for a new group of multi-potent plant extracts. Molecules. 14(6):2016-2031

\section{Publisher's Note}

Springer Nature remains neutral with regard to jurisdictional claims in published maps and institutional affiliations.
Ready to submit your research? Choose BMC and benefit from:

- fast, convenient online submission

- thorough peer review by experienced researchers in your field

- rapid publication on acceptance

- support for research data, including large and complex data types

- gold Open Access which fosters wider collaboration and increased citations

- maximum visibility for your research: over $100 \mathrm{M}$ website views per year

At BMC, research is always in progress.

Learn more biomedcentral.com/submissions 